\title{
Application of inorganic and liquid organic bio-fertilizers affects the vegetative growth and rhizobacteria populations of eight banana cultivars
}

\author{
TRI HANDAYANI", TIRTA KUMALA DEWI, DIYAH MARTANTI, YUYU SURYASARI POERBA, \\ SARJIYA ANTONIUS, WITJAKSONO \\ Research Center for Biology, Indonesia Institute of Sciences. Cibinong Science Center, J1. Raya Jakarta Bogor Km. 46 Cibinong, Bogor 16911, West \\ Java, Indonesia. Tel. +62-21-8765066, ^email: trihandayani08@gmail.com
}

Manuscript received: 30 December 2020. Revision accepted: 12 February 2021.

\begin{abstract}
Handayani T, Dewi TK, Martanti D, Poerba YS, Antonius S, Witjaksono. 2021. Application of inorganic and liquid organic bio-fertilizers affect the vegetative growth and rhizobacteria populations of eight banana cultivars. Biodiversitas 22: 1261-1271. Banana (Musa spp.) is generally cultivated subsistent as backyard crop or intensively in plantation with application of large amounts of inorganic fertilizers to improve yields. An application of bio-fertilizer may reduce the use of inorganic fertilizer and therefore may ensure sustainable production including banana production. This research evaluated the application of liquid organic bio-fertilizer (LOB) and inorganic fertilizers on vegetative growth and soil microbial population of banana plants. The LOB and inorganic fertilizer were tested in composition of (i) 100\% inorganic fertilizer (NPK), (ii) 50\% NPK + $100 \%$ LOB, (iii) 100\% LOB; on eight banana cultivars, i.e., Mas Kirana (AA), Cavendish (AAA), Barangan (AAA), Raja Bulu (AAB), Raja Lido (AAB), Raja Sereh (AAB), Tanduk $(\mathrm{AAB})$, and Kepok $(\mathrm{ABB})$. The results showed that for most of the cultivar tested, the vegetative growth rates were not significantly different between treatment of $100 \%$ NPK and LOB in combination with 50\% NPK fertilizer. The LOB application improved soil microbial population, including PGPR with a specific function such as IAA producing, phosphate solubilizing, and protease enzyme activity. The application LOB alone was insufficient to support banana's vegetative growth to the level incurred by even a moderate rate of inorganic fertilizer application.
\end{abstract}

Keywords: Banana, liquid organic bio-fertilizer, microbial population, PGPR, vegetative growth

Abbreviations: LOB: Liquid Organic Bio-fertilizer; PGPR: Plant Growth Promoting Rhizobacteria; WAP: Week After Planting

\section{INTRODUCTION}

Banana is one of the fruits that is widely grown and consumed by the Indonesian people. Bananas are generally grouped into cultivated, mostly seedless bananas and some seedy banana for spices and wild seeded bananas. Indonesia is known to have a wide variety of bananas, both cultivated and wild bananas (Hapsari 2014, Poerba et al 2018; Ernawiati et al. 2018, Poerba et al. 2019); this is because Indonesia is the center of origin and genetic diversity of the wild Musa acuminata Colla species (Nasution and Yamada 2001; Perrier et al. 2011; Li et al 2013) which is one of the ancestors of the cultivated bananas that exist. In Indonesia, bananas are commonly planted as a backyard crop, home garden, or mix with other crops in a smallholding system ( $\leq 1 \mathrm{ha})$. The varieties planted depend on local commercial varieties (Suyamto and Sutanto 2012; Danarto and Hapsari 2015). Bananas are also grown as border plants that mark land ownership, planted subsistent at the steep hills, riverbanks with very minimum tending. However, some large commercial plantations have been operational for some time, including a private company and a few state-own companies (Molina et al. 2019).

While as a backyard crop, bananas may not be intensively fertilized inorganically, in commercial cultivation, a large number of inorganic fertilizers, especially macronutrients like nitrogen, phosphate, and potassium, are intensively applied to the soil to improve yields. However, those common practices cause high production costs and hazardous to the environment, especially in soil fertility in the long run. Recently, eco-friendly biofertilizers have been applied to reduce inorganic fertilizers costs and avoid pollution (El Moniem et al. 2008).

Bio-fertilizers are composed of plant growth-promoting rhizobacteria (PGPR), a group of bacteria that is actively colonizing plant roots, increasing plant growth, and suppressing phytopathogens (Gupta et al. 2015; Santosa et al. 2018). Rhizobacteria promote the growth and yield of agriculturally important crops grown under different soil and climatic conditions (Mia et al. 2005). PGPR produce plant hormones, i.e., auxin, gibberellin, and cytokinin, promote phosphate and potassium solubilization, and perform nitrogen fixation, which constitutes important natures organic bio-fertilizers (Dewi et al. 2015). PGPRbased bio-fertilizers with their natures may play important roles in maintaining soil fertility (Posada et al. 2016; Gamez et al. 2019).

Many bio-fertilizers are available in the market, with single, double, or multiple microbes as the active agents. 
Many institutions have also developed their bio-fertilizer formulations with their specific microbe isolates for their particular purposes. According to the Minister of Agriculture, all formulations are subject to quality testing and registering based on Indonesian National Standards (SNI) (PP No. 01/2019). We also have developed our biofertilizer 'Beyonic' and formulated it either in solid or liquid form. The liquid organic bio-fertilizers (LOB) 'Beyonic' LIPI contains selective PGPRs isolated and screened from various Indonesian ecosystems. Application LOB 'Beyonic' increased yields $25-30 \%$ on multiple crops in various ecosystems, which corresponded with increasing urease, phosphomonoesterase, and respiration activity of the soil, yet reducing greenhouse gas (GHG) emission (Antonius et al. 2012). However, this formulation has not been applied to a banana plantation.

Information on bio-fertilizer application for increasing banana production for diverse cultivars in the Indonesian agro-ecological system is still lacking. Some reports from other countries such as Malaysia demonstrated increased yield in the range of $35-51 \%$ with bio-fertilizer inoculation combined with reduced $\mathrm{N}$ application (Mia et al. 2010). Bio-fertilizer also significantly promoted plant growth, increased chitinase, and $\beta$-1,3-glucanase activities by $55 \%$ $65 \%$ and $17.3 \%-120.1 \%$ banana roots (Zhang et al. 2014). Gurav and Jadhav (2013) reported that using biofertilization from feather biomass for banana cultivation not only increased protein, amino acid, reducing sugar, chlorophyll, and proline content, but also enhanced the antioxidant potential of banana fruit, which was assessed using 2, 2-diphenyl-1-picrylhydrazyl, ferric reducing/ antioxidant power, and $\mathrm{N}, \mathrm{N}$-dimethyl-p-phenylenediamine. Application of organic amendment could improve biological properties and enhance the production plant (Gurav and Jadhav 2013).

This study aimed to evaluate the effect of liquid organic bio-fertilizer 'Beyonic' application on eight cultivated varieties of bananas on their vegetative growths and their root zone's soil microbial abundance especially IAA producing bacteria, protease producing bacteria, and phosphate solubilizing bacteria.

\section{MATERIALS AND METHODS}

The banana plants were grown at the experimental field in Cibinong Bogor (S 06²9; E 106 $\left.{ }^{\circ} 51\right)$. Soil classified as clay loam with soil $\mathrm{pH} 4.9-5.8$, soil fertility levels is low with $1-2 \% \mathrm{C} ; 0.1-0.2 \% \mathrm{~N}$ and $\mathrm{C} / \mathrm{N}$ about $10-11$, with the rainfed condition, during 2016-2017.

The experimental design used was a split-plot randomized complete block design, with banana cultivars as the main plot and fertilizer application (Table 1) as the subplot, and five banana plants as replications. Fertilizer application combination (Table 1) was tested on 8 banana cultivars; (i) Mas Kirana (AA), (ii) Cavendish (AAA), (iii) Barangan (AAA), (iv) Raja Lido (AAB), (v) Raja Bulu (AAB), (vi) Raja Sereh (AAB), (vii) Tanduk (AAB), and (viii) Kepok (ABB).
Table 1. Fertilizer treatment description and nutrient rates used in the field experiment

\begin{tabular}{|c|c|c|c|}
\hline \multirow[t]{2}{*}{ Treatments } & \multicolumn{3}{|c|}{ Fertilizer rate per plant } \\
\hline & NPK1 & KCl2 & LOB 'Beyonic' \\
\hline $\mathrm{F} 1=100 \% \mathrm{NPK}$ & $250 \mathrm{~g}$ & $160 \mathrm{~g}$ & - \\
\hline $\mathrm{F} 2=\mathrm{LOB}+50 \% \mathrm{NPK}$ & $125 \mathrm{~g}$ & $80 \mathrm{~g}$ & $\begin{array}{c}1 \mathrm{~L} \text { per plant }(25 \\
\left.\mathrm{mL} \mathrm{L}^{-1}\right)\end{array}$ \\
\hline $\mathrm{F} 3=100 \% \mathrm{LOB}$ & - & - & $\begin{array}{l}1 \mathrm{~L} \text { per plant } \\
\left.\mathrm{mL} \mathrm{L}^{-1}\right)\end{array}$ \\
\hline
\end{tabular}

Note: Inorganic fertilizer 1) NPK 16:16:16 = 16\% N (Nitrogen), $16 \% \mathrm{P}_{2} \mathrm{O}_{5}$ (Phosphate), $16 \% \mathrm{~K}_{2} \mathrm{O}$ (Kalium); 2) $\mathrm{KCl}=$ fertilizers contents $60 \% \mathrm{~K}_{2} \mathrm{O}$ (Kalium); The inorganic fertilizer applied at 0 , 12 and 24 week after planting (WAP); LOB 'Beyonic' applied every 2 weeks until 12 WAP, LOB concentrate 25 mLLOB per liter water

Seedlings of bananas were derived from tissue culture propagation and had at least 4 to 6 leaves. Seedlings from each cultivar were planted in the planting holes, with a hole size of $50 \mathrm{~cm} \times 50 \mathrm{~cm} \times 50 \mathrm{~cm}$ (length $\times$ width $\times$ depth) and a spacing distance of $2.5 \mathrm{~m} \times 2.5 \mathrm{~m}$. Decomposed manure (15 kg per planting hole) and dolomite $\left(1\right.$ ton $\left.\mathrm{ha}^{-1}\right)$ were applied one week before planting. Weeding was carried out at bimonthly intervals. Inorganic fertilizer was applied at 0 , 12, and 24 WAP, while LOB 'Beyonic' was applied every two weeks until 12 WAP. LOB was diluted in the proportion of $25 \mathrm{ml}$ in 1 liter of water. The diluted LOB with a 1 liter per plant dose was applied by pouring it into the root zone.

LOB was prepared by inoculating PGPR formula as an inoculant in the mixing growth media consisting of a mixture of brown sugar, molasse, green bean sprout, fish meal, cornmeal, agar, eggs, rock phosphate, and coconut water of young fruits. All broth components that included raw materials were boiled except the eggs and the coconut water. The starter of LOB was inoculated into the prepared fermentation broth with egg and young coconut water and fermented for 21 days under continuous aeration and agitation at about $40 \mathrm{rpm}$. Inoculant formula consisted of 10 isolates of Burkholderia's family, including Pseudomonas, three species of Bacillus, Pseudochrobactrum, Ochrobactrum, Brevundimonas, Brevibacillus, and Microbacterium (Antonius et al. 2019 with ID Patent No. 000064813).

The data on plant vegetative growth, including the pseudostem height, the diameter of pseudostem, number of leaves, leaf length, and leaf width, were collected every four weeks $(0,4,8,12$, and 16 weeks after planting, WAP). The pseudostem height was measured from the ground level to the base of emerging leaves (crown). The pseudostem diameter was measured at $5-10 \mathrm{~cm}$ above ground, while the leaf length and width were observed on the third from the newest leaf.

Soil samples were collected at 0 WAP shortly before the treatment of fertilizer and at 12 WAP. Soil and root were collected from the banana plant's rhizosphere at a depth of $10 \mathrm{~cm}$ to $15 \mathrm{~cm}$. One hundred grams of soil were taken from each treatment in three replicates using the composite method. The soil and root samples obtained was 
mixed and collected into the polybag and stored in the cooler box. Ten grams of soil sample was stored in Erlenmeyer flask and homogenized with distilled water $(90$ $\mathrm{mL})$ by shaker for $30 \mathrm{~min}$ and decimally diluted $\left(10^{-3}, 10^{-4}\right.$, $\left.10^{-5}, 10^{-6}\right)$ in sterile distilled water. The last dilutions were taken with a micropipette and spread on different specific cultural media, namely skim milk agar medium, tryptic soya agar medium and Pikovskaya agar medium for showing PGPR activity indicator of protease, IAA producing and phosphate solubilization, respectively. The general total population of bacteria was observed on nutrient agar medium. Phosphate solubilizing and protease enzyme-producing bacteria activities were scored from clear zone formation on the colonies. Total Plate Count Method was used to calculate the total population of bacteria (Cappucino and Sherman 1987; Moat et al. 2002, SNI 2897:2008)

Collected data on plant growth parameters were analyzed using Analysis of Variance (ANOVA) followed by Duncan Multiple Range Test (DMRT) comparison at a $5 \%$ level of significance using SAS System 9.1.

\section{RESULTS AND DISCUSSION}

\section{Plant growth response}

The ANOVA analysis (Table 2) showed that both fertilizer treatments and banana cultivars significantly affect plant vegetative growth responses. However, there was no interaction between the fertilizer treatments and the banana cultivars tested.

Fertilizer treatments demonstrated that the treatment of $100 \%$ LOB $+50 \%$ NPK was not significantly different from $100 \%$ NPK. Still, both were significantly higher than the treatment of LOB alone regarding all growth variables observed, including pseudostem height, the number of leaves, the diameter of pseudostem, leaf length, and leaf width (Table 3).

Generally, the average vegetative growth responses of 8 banana cultivars to fertilizer applications showed differences among cultivars. The diploid with genome Acuminata (AA), Mas Kirana, had significantly smaller plant morphology as indicated by pseudostem height and diameter with smaller leaf length and width than other cultivars tested. Meanwhile, cultivar Kepok, a triploid with the predominance genome of Balbisiana (ABB) showed the biggest plant morphology as indicated by pseudostem height and diameter and leaf size, even though its number of a leaf was among the lowest. Other cultivar tested, such as Raja (Raja Lido, Raja Bulu, and Raja Sereh), which are triploids with $2 \mathrm{~A}$ genome and $1 \mathrm{~B}$, tend to cluster and significantly bigger than the triploid AAA such as Cavendish and Barangan. Tanduk, even though it is a triploid AAB, had small morphology and tended to be smaller in diameter than triploid AAA (Table 3).

As represented by the pseudostem height up to 16 WAP, the bananas growth curve seemed to follow regular sigmoid growth curve, but at the early stage which was characterized by slow growth up to 8 WAP followed by more rapid growth henceforth (Figure 1). The effect of fertilization treatments on eight different banana cultivars showed significantly different $(\operatorname{Pr}>f=<0.0001)$. Still, the interaction between the two factors was no significant $(\operatorname{Pr}>f$ $=0.1196$ ) for the vegetative growth variable of pseudostem height at 12 WAP. Observation on the cultivar's growth regarding the pseudostem height (Figure 1) showed that they did not differ until 4 WAP but started to differ at 8 WAP. Referring to Figure 1, the difference in pseudostem height among three fertilizer treatments depends on the cultivars. However, generally, the fertilization treatment of inorganic fertilizer NPK resulted in the pseudostem's highest height, but not significantly different from the combination of LOB and 50\%NPK. Pseudostem height resulted from both treatments were significantly greater than that of the treatment of LOB alone. Cultivars of Cavendish and Barangan demonstrated significantly different growth rates of pseudostem height with inorganic fertilizer application and reduced it $(50 \%$ NPK $+100 \%$ LOB and LOB alone) could reduce the growth significantly (Figure 1). Therefore, compared to inorganic fertilizer application, the application of LOB alone generally incurred about $50 \%$ reduction on the pseudostem height for Cavendish, Barangan, Raja Lido, Raja Bulu, Mas Kirana, Raja Sereh, even though for Tanduk the growth reduction could reach over $60 \%$, while for Kepok the growth reduction occurred only around $23 \%$.

Table 2. Analysis of variance (ANOVA) summary for vegetative growth parameter of eight banana cultivars at different fertilizer treatments at 12 WAP

\begin{tabular}{lccccc}
\hline \multicolumn{1}{c}{ Source } & Pseudo-stem height & Number of leave & Diameter of pseudostem & Leaf length & Leaf width \\
\hline Fertilizer & $<0.0001 * *$ & $<0.0001 * *$ & $<0.0001 * *$ & $<0.0001 * *$ & $<0.0001 * *$ \\
Banana Cultivar & $<0.0001 * *$ & $<0.0001 * *$ & $<0.0001 * *$ & $<0.0001 * *$ & $<0.0001 * *$ \\
Replication & $0.3878 \mathrm{~ns}$ & $0.2718 \mathrm{~ns}$ & $0.6261 \mathrm{~ns}$ & $0.2546 \mathrm{~ns}$ & $0.2869 \mathrm{~ns}$ \\
Fertilizer*Replication & $0.7241 \mathrm{~ns}$ & $0.0188 *$ & $0.4735 \mathrm{~ns}$ & $0.4581 \mathrm{~ns}$ & $0.6302 \mathrm{~ns}$ \\
Fertilizer*Cultivar & $0.1196 \mathrm{~ns}$ & $0.0338 *$ & $0.1931 \mathrm{~ns}$ & $0.1806 \mathrm{~ns}$ & $0.2460 \mathrm{~ns}$ \\
$\%$ CV & 18.548 & 15.629 & 18.288 & 16.876 & 16.447 \\
\hline
\end{tabular}

Note: Value at each column are pr>f, * significant at the 0.05 level, ** significant at the 0.01 level, ns not-significant. WAP: week after planting 
Table 3. The responses of vegetative growth variables at different fertilizer application treatments on eight banana cultivars at 12 WAP

\begin{tabular}{|c|c|c|c|c|c|c|c|c|c|c|}
\hline \multirow{2}{*}{$\begin{array}{c}\text { Treatments } \\
\text { Fertilizers applicatio }\end{array}$} & \multicolumn{2}{|c|}{$\begin{array}{c}\text { Pseudo-stem height } \\
(\mathrm{cm})\end{array}$} & \multicolumn{2}{|c|}{ Number of leave } & \multicolumn{2}{|c|}{$\begin{array}{c}\text { Diameter of } \\
\text { pseudostem }(\mathbf{c m})\end{array}$} & \multicolumn{2}{|l|}{$\begin{array}{c}\text { Leaf length } \\
(\mathrm{cm})\end{array}$} & \multicolumn{2}{|l|}{$\begin{array}{c}\text { Leaf width } \\
\text { (cm) }\end{array}$} \\
\hline & & & & & & & & & & \\
\hline NPK & $120.30 \pm 27.49$ & $\mathrm{a}$ & $11.76 \pm 1.62$ & $\mathrm{a}$ & $10.62 \pm 2.18$ & $\mathrm{a}$ & $112.16 \pm 26.61$ & a & $51.12 \pm 8.23$ & $\mathrm{a}$ \\
\hline $\mathrm{LOB}+50 \% \mathrm{NPK}$ & $115.76 \pm 40.65$ & $\mathrm{a}$ & $11.57 \pm 2.01$ & $\mathrm{a}$ & $10.14 \pm 2.94$ & $\mathrm{a}$ & $108.73 \pm 33.19$ & $\mathrm{a}$ & $48.61 \pm 12.54$ & $\mathrm{a}$ \\
\hline LOB & $67.68 \pm 28.79$ & $\mathrm{~b}$ & $8.00 \pm 2.62$ & $\mathrm{~b}$ & $6.25 \pm 1.93$ & $\mathrm{~b}$ & $70.45 \pm 24.75$ & $\mathrm{~b}$ & $32.68 \pm 11.01$ & $\mathrm{~b}$ \\
\hline \multicolumn{11}{|l|}{ Banana cultivars } \\
\hline Mas kirana (AA) & $69.69 \pm 26.63$ & $\mathrm{e}$ & $10.23 \pm 3.06$ & $\mathrm{c}$ & $6.08 \pm 2.08$ & $\mathrm{f}$ & $65.15 \pm 24.65$ & $\mathrm{~d}$ & $32.73 \pm 10.90$ & $\mathrm{e}$ \\
\hline Cavendish (AAA) & $74.62 \pm 27.80$ & $\mathrm{e}$ & $10.54 \pm 1.90$ & $\mathrm{bc}$ & $8.24 \pm 3.05$ & ed & $76.08 \pm 27.32$ & d & $40.46 \pm 12.67$ & $\mathrm{~cd}$ \\
\hline Barangan (AAA) & $89.53 \pm 22.56$ & $\mathrm{~cd}$ & $11.73 \pm 3.41$ & $a b$ & $8.41 \pm 2.06$ & ed & $96.40 \pm 21.31$ & $\mathrm{c}$ & $42.73 \pm 9.69$ & $\mathrm{c}$ \\
\hline Tanduk (AAB) & $79.73 \pm 40.80$ & de & $9.00 \pm 2.83$ & $\mathrm{~d}$ & $7.34 \pm 3.31$ & $\mathrm{e}$ & $70.27 \pm 30.53$ & d & $36.23 \pm 15.62$ & ed \\
\hline Raja lido (AAB) & $97.85 \pm 31.45$ & $\mathrm{c}$ & $10.77 \pm 3.14$ & $\mathrm{bc}$ & $9.15 \pm 2.44$ & $\mathrm{~cd}$ & $113.92 \pm 25.30$ & $\mathrm{~b}$ & $44.04 \pm 8.50$ & $\mathrm{c}$ \\
\hline Raja bulu (AAB) & $123.00 \pm 34.47$ & $\mathrm{~b}$ & $12.21 \pm 1.19$ & $\mathrm{a}$ & $10.51 \pm 2.90$ & $\mathrm{~b}$ & $120.14 \pm 29.70$ & $a b$ & $52.04 \pm 12.39$ & $\mathrm{~b}$ \\
\hline Raja sereh $(\mathrm{AAB})$ & $116.40 \pm 34.77$ & $\mathrm{~b}$ & $10.53 \pm 2.39$ & bc & $10.02 \pm 2.96$ & $\mathrm{bc}$ & $100.27 \pm 28.07$ & $\mathrm{c}$ & $44.20 \pm 11.23$ & $\mathrm{c}$ \\
\hline Kepok (ABB) & $153.64 \pm 26.42$ & $\mathrm{a}$ & $8.36 \pm 1.28$ & $\mathrm{~d}$ & $11.90 \pm 1.83$ & $\mathrm{a}$ & $131.93 \pm 18.18$ & $\mathrm{a}$ & $59.43 \pm 5.72$ & $\mathrm{a}$ \\
\hline
\end{tabular}

Note: Value means \pm St Dev from 8 banana cultivars and different fertilizer applications. The same letter in the same column does not differ significantly at the 0.05 level by DMRT

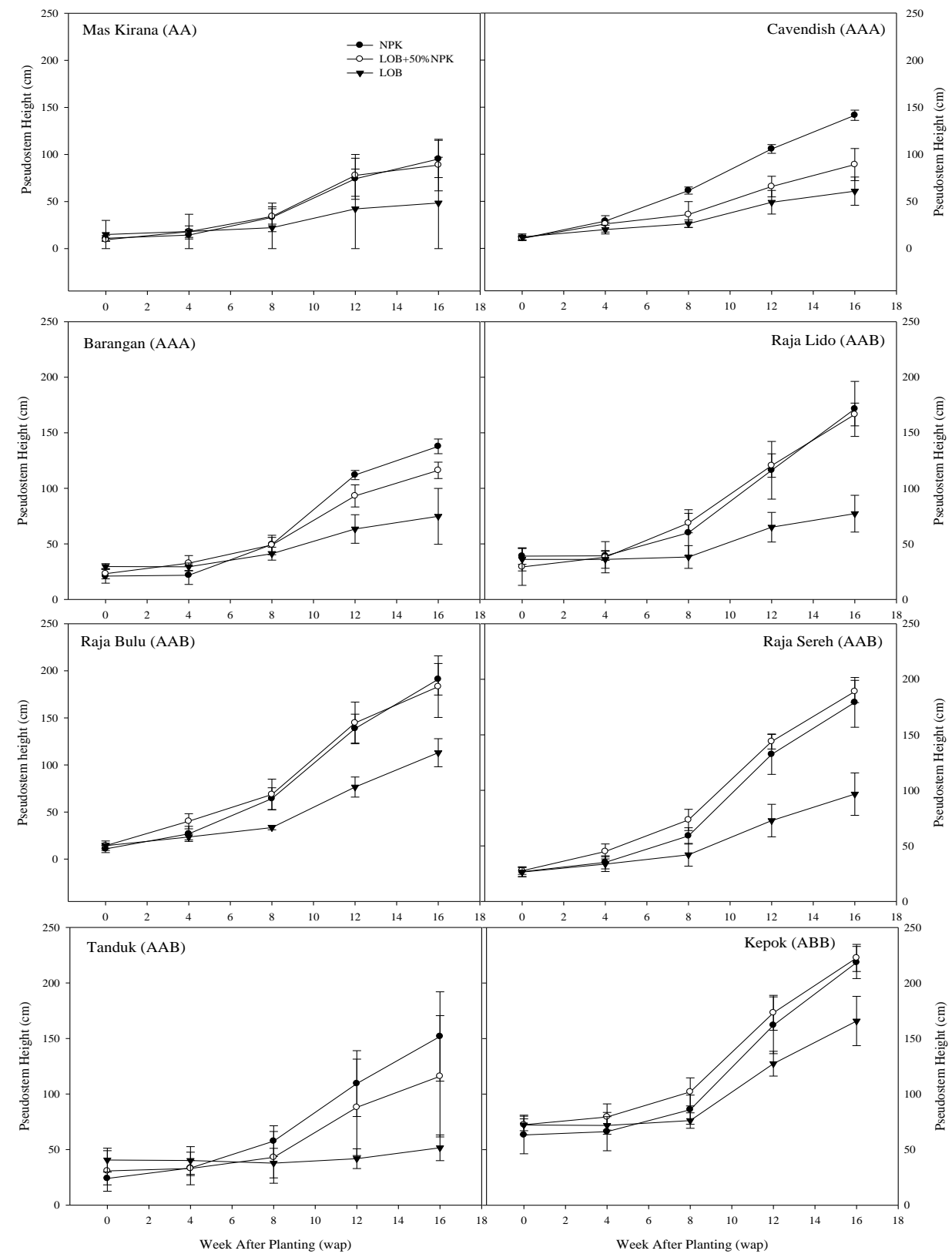

Figure 1. Growth curve of pseudostem height $(\mathrm{cm})$ of 8 banana cultivars in 3 different fertilization treatments up through 16 WAP 
Table 4. Vegetative growth parameters of eight cultivars at different fertilizer application treatments at 12 WAP

\begin{tabular}{|c|c|c|c|c|c|c|c|c|c|}
\hline \multirow{3}{*}{$\begin{array}{c}\text { Cultivars } \\
\text { Mas Kirana (AA) }\end{array}$} & \multirow{3}{*}{$\begin{array}{l}\begin{array}{c}\text { Fertilizer } \\
\text { application }\end{array} \\
\mathrm{NPK}\end{array}$} & \multicolumn{2}{|c|}{$\begin{array}{c}\text { Diameter of } \\
\text { pseudostem }(\mathrm{cm})\end{array}$} & \multicolumn{2}{|c|}{ Number of leaves } & \multicolumn{2}{|c|}{ Leaf length (cm) } & \multicolumn{2}{|c|}{ Leaf width $(\mathrm{cm})$} \\
\hline & & \multicolumn{8}{|c|}{ Mean \pm Std error - } \\
\hline & & $6.20 \pm 2.43$ & a & $11.40 \pm 0.71$ & $\mathrm{a}$ & $61.60 \pm 28.55$ & $\mathrm{a}$ & $35.10 \pm 12.99$ & $\mathrm{a}$ \\
\hline & $\mathrm{LOB}+1 / 2 \mathrm{NPK}$ & $6.88 \pm 1.95$ & $\mathrm{a}$ & $12.00 \pm 1.52$ & $\mathrm{a}$ & $75.60 \pm 25.94$ & $\mathrm{a}$ & $34.50 \pm 11.31$ & $\mathrm{a}$ \\
\hline \multirow{4}{*}{ Cavendish (AAA) } & LOB & $4.04 \pm 1.13$ & $\mathrm{~b}$ & $6.80 \pm 2.39$ & $\mathrm{~b}$ & $47.20 \pm 13.81$ & $\mathrm{~b}$ & $23.00 \pm 6.09$ & $\mathrm{~b}$ \\
\hline & NPK & $11.62 \pm 0.53$ & $\mathrm{a}$ & $11.60 \pm 0.89$ & $\mathrm{a}$ & $107.00 \pm 7.81$ & $\mathrm{a}$ & $53.80 \pm 4.49$ & $\mathrm{a}$ \\
\hline & $\mathrm{LOB}+1 / 2 \mathrm{NPK}$ & $7.54 \pm 1.12$ & $\mathrm{~b}$ & $10.67 \pm 0.58$ & $\mathrm{a}$ & $67.00 \pm 10.58$ & $\mathrm{~b}$ & $39.33 \pm 6.03$ & $\mathrm{~b}$ \\
\hline & LOB & $5.29 \pm 1.16$ & $\mathrm{c}$ & $9.40 \pm 2.61$ & $\mathrm{a}$ & $50.60 \pm 7.33$ & $\mathrm{c}$ & $27.80 \pm 4.44$ & $\mathrm{c}$ \\
\hline \multirow{3}{*}{ Barangan (AAA) } & NPK & $9.90 \pm 0.42$ & $\mathrm{a}$ & $13.60 \pm 2.61$ & $\mathrm{a}$ & $111.40 \pm 6.27$ & $\mathrm{a}$ & $49.40 \pm 2.82$ & $\mathrm{a}$ \\
\hline & $\mathrm{LOB}+1 / 2 \mathrm{NPK}$ & $9.52 \pm 0.85$ & $\mathrm{a}$ & $14.00 \pm 1.14$ & $\mathrm{a}$ & $104.80 \pm 14.65$ & a & $46.80 \pm 5.97$ & $\mathrm{a}$ \\
\hline & LOB & $5.82 \pm 1.16$ & $\mathrm{~b}$ & $7.60 \pm 0.71$ & $\mathrm{~b}$ & $73.00 \pm 16.78$ & $\mathrm{~b}$ & $32.00 \pm 8.05$ & $\mathrm{~b}$ \\
\hline \multirow[t]{3}{*}{ Raja Lido (AAB) } & NPK & $10.65 \pm 2.09$ & $\mathrm{a}$ & $12.50 \pm 1.29$ & $\mathrm{a}$ & $129.80 \pm 18.38$ & $\mathrm{a}$ & $49.50 \pm 3.70$ & $\mathrm{a}$ \\
\hline & $\mathrm{LOB}+1 / 2 \mathrm{NPK}$ & $10.83 \pm 0.58$ & $\mathrm{a}$ & $12.75 \pm 0.96$ & a & $132.75 \pm 5.32$ & $\mathrm{a}$ & $50.50 \pm 1.73$ & $\mathrm{a}$ \\
\hline & LOB & $6.60 \pm 1.05$ & $\mathrm{~b}$ & $7.80 \pm 3.11$ & $\mathrm{~b}$ & $86.80 \pm 12.03$ & $\mathrm{~b}$ & $34.50 \pm 4.36$ & $\mathrm{~b}$ \\
\hline \multirow[t]{3}{*}{ Raja Bulu (AAB) } & NPK & $11.42 \pm 1.57$ & $\mathrm{a}$ & $12.80 \pm 0.84$ & $\mathrm{a}$ & $132.80 \pm 13.74$ & $\mathrm{a}$ & $56.40 \pm 7.96$ & $\mathrm{a}$ \\
\hline & $\mathrm{LOB}+1 / 2 \mathrm{NPK}$ & $12.28 \pm 2.85$ & $\mathrm{a}$ & $12.60 \pm 1.30$ & $\mathrm{a}$ & $138.20 \pm 22.59$ & $\mathrm{a}$ & $59.60 \pm 9.66$ & $\mathrm{a}$ \\
\hline & LOB & $6.40 \pm 1.89$ & $\mathrm{~b}$ & $10.80 \pm 0.55$ & $\mathrm{~b}$ & $74.00 \pm 19.65$ & $\mathrm{~b}$ & $33.50 \pm 9.51$ & $\mathrm{~b}$ \\
\hline \multirow[t]{3}{*}{ Raja Sereh (AAB) } & NPK & $11.47 \pm 1.78$ & $\mathrm{a}$ & $11.40 \pm 2.35$ & $\mathrm{a}$ & $122.20 \pm 13.22$ & $\mathrm{a}$ & $49.80 \pm 2.77$ & $\mathrm{a}$ \\
\hline & $\mathrm{LOB}+1 / 2 \mathrm{NPK}$ & $12.23 \pm 1.02$ & $\mathrm{a}$ & $12.20 \pm 0.45$ & $\mathrm{a}$ & $113.20 \pm 4.60$ & $\mathrm{a}$ & $53.00 \pm 2.00$ & $\mathrm{a}$ \\
\hline & LOB & $6.37 \pm 1.08$ & $\mathrm{~b}$ & $8.00 \pm 1.34$ & $\mathrm{~b}$ & $65.40 \pm 15.21$ & $\mathrm{~b}$ & $29.80 \pm 5.89$ & $\mathrm{~b}$ \\
\hline \multirow[t]{3}{*}{ Tanduk (AAB) } & NPK & $9.68 \pm 2.81$ & $\mathrm{a}$ & $10.60 \pm 1.52$ & $\mathrm{a}$ & $90.80 \pm 25.65$ & $\mathrm{a}$ & $46.80 \pm 10.57$ & $\mathrm{a}$ \\
\hline & $\mathrm{LOB}+1 / 2 \mathrm{NPK}$ & $7.74 \pm 3.61$ & $a b$ & $9.60 \pm 3.11$ & $a b$ & $75.60 \pm 31.89$ & $\mathrm{ab}$ & $39.00 \pm 16.39$ & $a b$ \\
\hline & LOB & $4.59 \pm 0.97$ & $\mathrm{~b}$ & $6.80 \pm 2.51$ & $\mathrm{~b}$ & $44.40 \pm 13.72$ & $\mathrm{~b}$ & $22.90 \pm 10.13$ & $\mathrm{~b}$ \\
\hline \multirow[t]{3}{*}{ Kepok (ABB) } & NPK & $11.96 \pm 2.36$ & $a b$ & $8.60 \pm 0.55$ & $a b$ & $131.20 \pm 33.5$ & $\mathrm{ab}$ & $58.90 \pm 9.95$ & $a b$ \\
\hline & $\mathrm{LOB}+1 / 2 \mathrm{NPK}$ & $13.22 \pm 0.72$ & $\mathrm{a}$ & $8.60 \pm 1.52$ & $\mathrm{a}$ & $141.80 \pm 8.73$ & $\mathrm{a}$ & $62.80 \pm 1.79$ & $\mathrm{a}$ \\
\hline & LOB & $9.80 \pm 0.62$ & $\mathrm{~b}$ & $7.40 \pm 1.67$ & $\mathrm{~b}$ & $111.60 \pm 3.97$ & $\mathrm{~b}$ & $53.30 \pm 3.15$ & $\mathrm{~b}$ \\
\hline
\end{tabular}

Note: value in each column are means \pm Std Error, the same letter in the same column and same cultivar do not differ significantly at the 0.05 level by DMRT

The effect of fertilization and cultivar on other vegetative growth response variable such as pseudostem diameter, number of leaves, and leaf length and width were essentially similar to that of pseudostem height (Table 4), i.e., no significant difference on those growth response variables between inorganic fertilizer treatment and the use of LOB but with $50 \%$ reduction of inorganic fertilizer, there were significant growth reductions in treatment of LOB alone for cultivar, except for Cavendish. Cavendish, being the most importantly traded cultivars, showed significant growth reduction with reduction of inorganic fertilizer as demonstrated in the pseudostem diameters and leaves' size, but not in the number of leaves. Growth reduction due to the replacement of inorganic fertilizer with LOB alone accounts for about $40-50 \%$ for most of the cultivar tested, the reduction of more than $50 \%$ occurred for Tanduk while reducing only $20-30 \%$ occurred on Kepok. Application of LOB 'Beyonic' could prevent significant plant growth reduction if combined with inorganic fertilizers at least $50 \%$ of the recommended dosage.

\section{The population of plant growth-promoting rhizobacteria}

The total population of bacteria was observed under a specific medium. The result showed that the soil samples contain bacteria with some activity, including phosphate solubilizing bacteria, IAA hormone-producing bacteria, and protease producing bacteria. The number of the total population of bacteria in the banana plant's soil was affected by each treatment. The different number of bacterial populations might be affected by nutrient content in the soil. The condition soil may have a variety of nutritional content that affects the number of microbial populations. Organic fertilizer (manure) was added in the planting hole before treatment affects the soil microbial population at $0 \mathrm{WAP}$, respectively.

The ANOVA of 0 WAP showed that the total population of bacteria on fertilizer treatment was significantly different; however, the total population of IAA producing bacteria, protease producing bacteria, and phosphate solubilizing bacteria was not significant. At 0 WAP, the interaction between fertilizer and cultivar was significant, with each cultivar not significantly different, even though the fertilizer treatment was not applied. At 0 WAP, the planting method that included decomposed manure before treatment and the banana planting materials that could already carry some bacteria in their root zone, which may be different with different cultivars altogether, might have affected the total population bacteria IAA producing bacteria and phosphate solubilizing bacteria. Due to these circumstances, the experiment was designed in a split-plot randomized complete block design with banana cultivars as the main plot and fertilizer application as the subplot to reduce error in soil microbial population differences. 
Table 5. Analysis of variance (ANOVA) summary for microbial population parameter of eight banana cultivars at different fertilizer treatment at 0 and $12 \mathrm{WAP}$

\begin{tabular}{|c|c|c|c|c|}
\hline Treatment & $\begin{array}{c}\text { Total Bacteria } \\
\left(\text { CFU mL } \mathbf{~ L}^{-1}\right)\end{array}$ & $\begin{array}{c}\text { IAA Producing } \\
\text { Bacteria }\left(\mathrm{CFU} \mathbf{~ m L}^{-1}\right) \\
\end{array}$ & $\begin{array}{l}\text { Protease Producing } \\
\text { Bacteria }\left(\mathrm{CFU} \mathbf{~ m L}^{-1}\right) \\
\end{array}$ & $\begin{array}{c}\text { Phosphate Solubilizing } \\
\text { Bacteria }\left(\mathrm{CFU} \mathbf{~ m L}^{-1}\right)\end{array}$ \\
\hline \multicolumn{5}{|l|}{ O WAP } \\
\hline Fertilizer & $0.0397 *$ & $0.0861 \mathrm{~ns}$ & $0.1628 \mathrm{~ns}$ & $0.0836 \mathrm{~ns}$ \\
\hline Banana Cult. & $0.1308 \mathrm{~ns}$ & $0.8401 \mathrm{~ns}$ & $0.0111 *$ & $0.5127 \mathrm{~ns}$ \\
\hline Rep & $0.0019 * *$ & $0.6612 \mathrm{~ns}$ & $0.6663 \mathrm{~ns}$ & $0.0603 \mathrm{~ns}$ \\
\hline Fertilizer*Rep & $0.5537 \mathrm{~ns}$ & $0.1563 \mathrm{~ns}$ & $0.6984 \mathrm{~ns}$ & $0.6199 \mathrm{~ns}$ \\
\hline Fertilizer*Cult. & $<.0001 * *$ & $0.0005 * *$ & $0.0704 \mathrm{~ns}$ & $0.0009 * *$ \\
\hline$\% \mathrm{CV}$ & 21.66882 & 31.87862 & 31.73933 & 33.11039 \\
\hline \multicolumn{5}{|l|}{12 WAP } \\
\hline Fertilizer & $0.0488 *$ & $<.0001 * *$ & $<.0001 * *$ & $<.0001 * *$ \\
\hline Banana Cult. & $0.2263 \mathrm{~ns}$ & $0.0111 *$ & $0.0028 * *$ & $0.0016 * *$ \\
\hline Rep & $0.0027 * *$ & $0.0120 *$ & $0.0128 *$ & $0.0013 * *$ \\
\hline Fertilizer*Rep & $0.9767 \mathrm{~ns}$ & $0.2451 \mathrm{~ns}$ & $0.4080 \mathrm{~ns}$ & $0.3811 \mathrm{~ns}$ \\
\hline Fertilizer*Cult. & $0.3717 \mathrm{~ns}$ & $0.6976 \mathrm{~ns}$ & $0.4341 \mathrm{~ns}$ & $0.0753 \mathrm{~ns}$ \\
\hline$\% \mathrm{CV}$ & 59.88767 & 61.92463 & 53.43413 & 38.49258 \\
\hline
\end{tabular}

Note: value at each column are pr>f, * significant at the 0.05 level, ** significant at the 0.01 level, ns non-significant
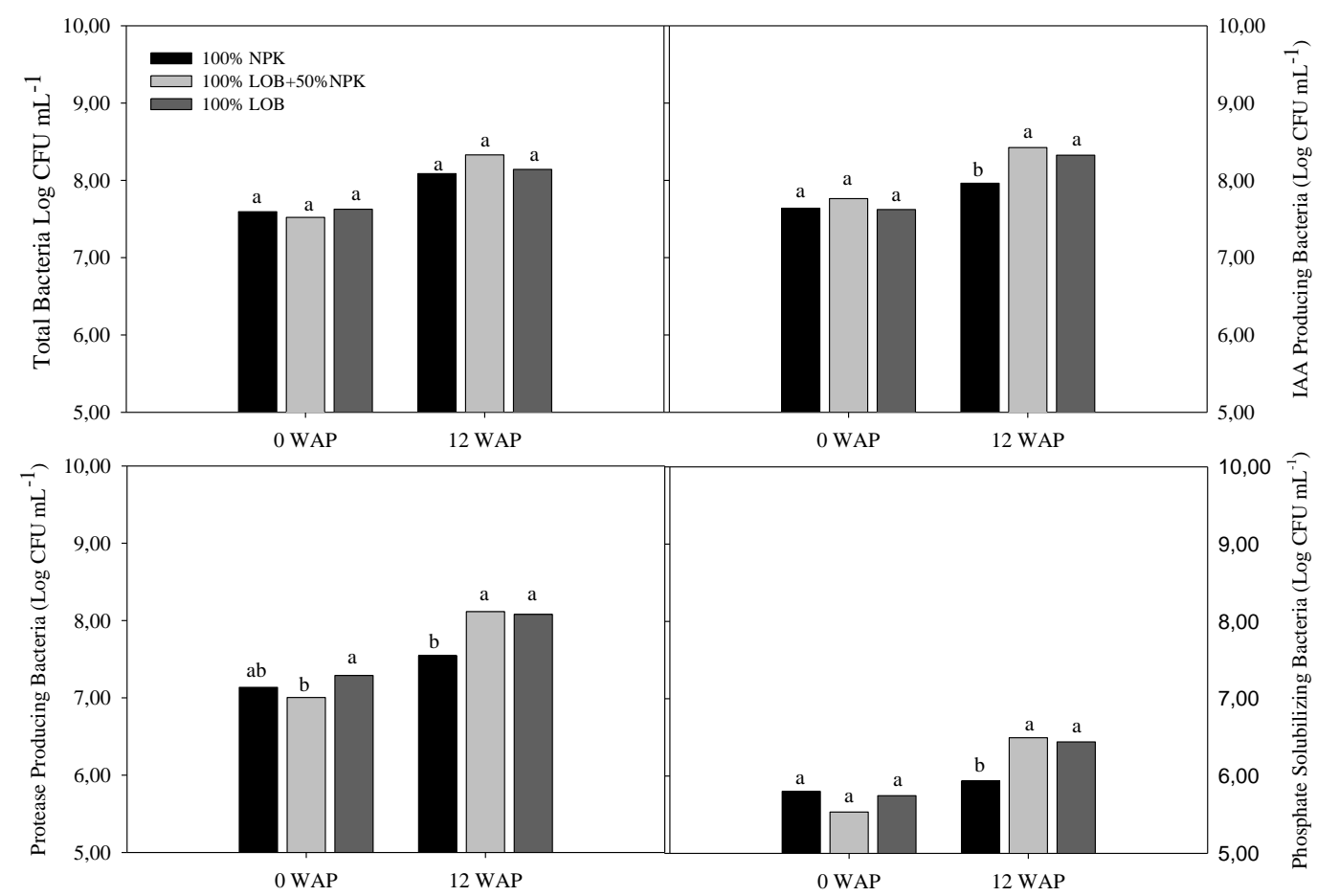

Figure 2. The bacterial population on each fertilizer application treatment at 0 and 12 WAP. Note: The same letter in the same week of each graph do not differ significantly at the 0.05 level by DMRT; the value of each histogram is means from 8 cultivars of banana at different fertilizer application

The ANOVA of 12 WAP compared to that of 0 WAP (Table 5) showed that there were generally increases in the level of significance of fertilizer application and cultivar on the total bacteria population, IAA producing bacteria, protease producing bacteria and phosphate solubilizing bacteria. However, at $12 \mathrm{WAP}$, the interaction between fertilizer and cultivar that were significant at 0 WAP became less pronounced regarding the PGPR variable, indicating that the effect of fertilizer application tends to have a similar effect for each cultivar, even though each cultivar were significantly different also.
A more detailed analysis of the PGPR population indicated a virtually homogenous population at 0 WAP when there was no fertilizer application to the plants. After 12 weeks of banana plant growth, there was a significant increase in those populations, at a rate of $2.4-17.4 \%$ depending on the kind of PGPR (Figure 2). Generally, PGPR was the lowest with $100 \%$ NPK, while a significantly higher PGPR population was found in the rhizosphere of plants treated with $50 \% \mathrm{NPK}+\mathrm{LOB}$, which was not significantly different from treatment LOB only (Figure 2). It is worth noting that inorganic fertilizer treatment only 
allowed the PGPR population to increase only 2.4-6.5\%, while with the application of $50 \% \mathrm{NPK}+\mathrm{LOB}$, the increase of PGPR population was $8.5-17.4 \%$, while with LOB only, the increase was only $6.8-12.1 \%$ (Figure 2).

Although the banana cultivar tested significantly affecting the PGPR population at $0 \mathrm{WAP}$, their population was around the scale of $5 \times 10^{7} \mathrm{CFU} \mathrm{mL} \mathrm{mL}^{-1}$ (7.7 Log CFU $\left.\mathrm{mL}^{-1}\right)$. However, after plant growth of 12 weeks, the PGPR population increased variably from $2.0 \%$ to over $23.0 \%$ regarding total bacteria population and PGPRs but depending on their specific function and the banana cultivar (Figure 3). Therefore, the application of fertilizer treatment increased bacterial population in each cultivar with different magnitude. For example, Mas Kirana (AA), Raja Bulu (AAB), Cavendish (AAA), Barangan (AAA) showed higher total bacterial count than that of Raja Lido (AAB), Raja Sereh (AAB), Tanduk (AAB), Kepok (ABB). Total population of IAA producing bacteria, protease producing bacteria in Barangan cultivar showed the highest number. Total population of phosphate solubilizing bacteria in Raja Lido cultivar was the highest.

Treatment of different fertilizers gave significant effect on total population of bacteria (Table 6). For the whole cultivars' tested application of LOB $+50 \%$ NPK increased total population of bacteria. Total population of IAA producing bacteria of Barangan cultivar was highest $\left(9.32 \times 10^{8} \mathrm{CFU} \mathrm{mL} \mathrm{m}^{-1}\right)$ on $12 \mathrm{WAP}$. On the other hand, total population bacteria in Raja Sereh cultivar significantly increased in all activities with LOB $+50 \%$ NPK treatment.

The increase of bacterial population as indicated by total bacteria after 12 weeks of planting were mostly attributed to the application LOB or $\mathrm{LOB}+50 \%$ NPK in almost all banana cultivars tested, except in 'Cavendish' and 'Tanduk'. For Cavendish, the increase of total bacteria occurred with NPK fertilizer, while for Tanduk there was no increase in total bacteria population. Total bacterial population in coinciding with increase of all functionally specific PGPR tested included IAA producing bacteria, protease producing bacteria and phosphate solubilizing bacteria for banana cultivars of Barangan, Raja Lido, Raja Bulu, and Kepok. While for Mas Kirana and Cavendish there were no significant increase in IAA producing bacteria. Interestingly, high population of bacteria due to NPK fertilizer did not correlate with high population of functional PGPR, in fact, that the increase of proteaseproducing bacteria occurred at treatment of $\mathrm{LOB}+50 \% \mathrm{NPK}$. It is also interesting to note that for Tanduk, even though total bacteria did not increase significantly after 12 weeks of plant growth, notable increase happened in population of IAA and proteaseproducing bacteria as well as phosphate solubilizing bacteria at the LOB only. Total population of phosphate solubilizing bacteria in Raja Lido cultivar showed the highest increase compared to other cultivars at the application of LOB only. Application LOB only or combined with reduced NPK generally increased population of rhizobacteria. However, even though total bacteria population did not seem to increase with LOB application, increase in population of one or more functional PGPR occurred in all cultivar tested. Therefore, application of LOB with or without NPK evidently increased population of functional PGPR in banana rhizosphere.

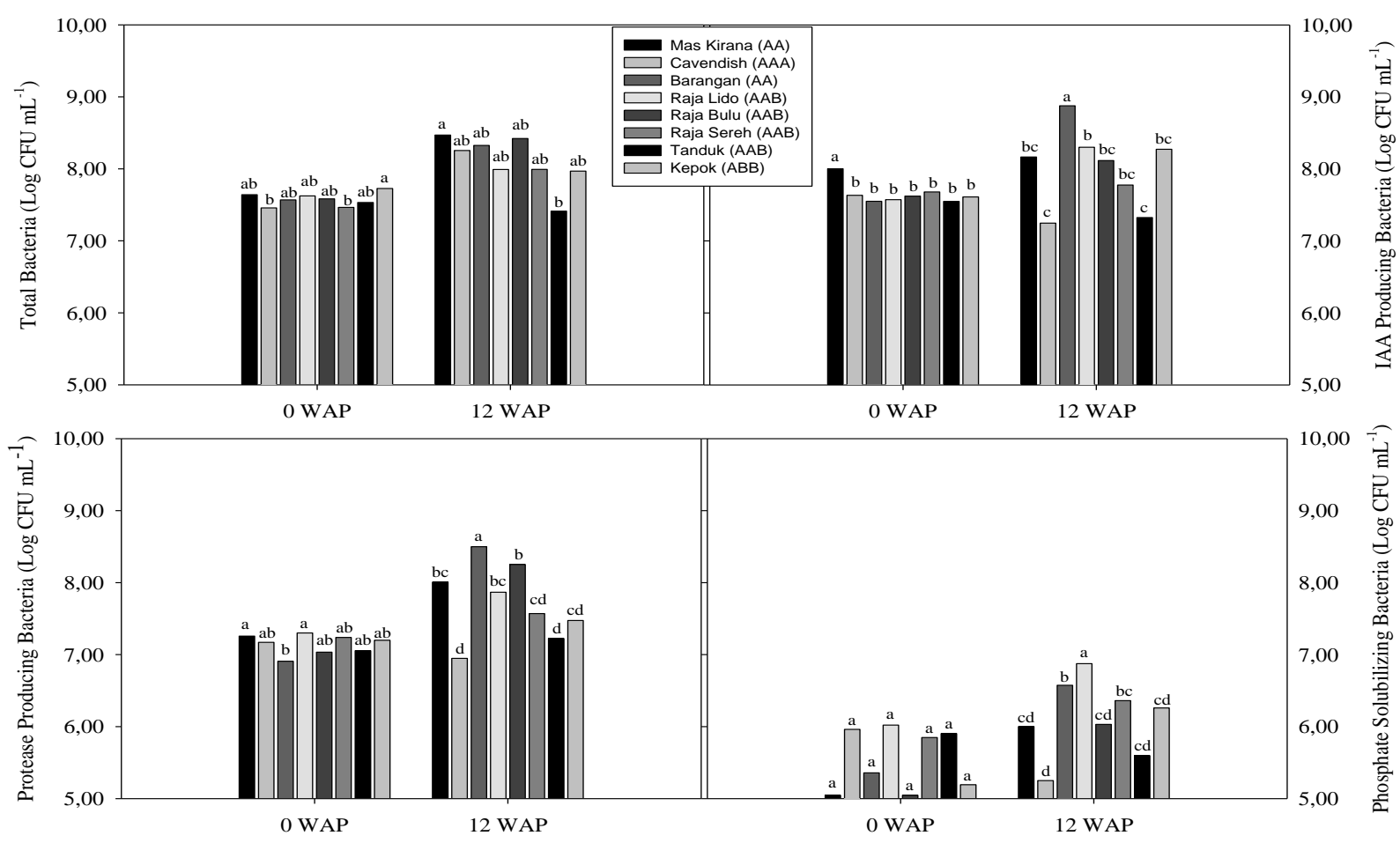

Figure 3. The bacterial population on each banana cultivars at 0 and 12 WAP. Note: The same letter in the same week on each graph do not differ significantly at the 0.05 level by DMRT; the value of each histogram cultivars is means from three different fertilizer application. 
Table 6. The microbial population on $0 \mathrm{WAP}$ to $12 \mathrm{WAP}$ of eight cultivars banana at different fertilizer treatment

\begin{tabular}{|c|c|c|c|c|c|c|c|c|c|}
\hline \multicolumn{2}{|c|}{ Treatments } & \multicolumn{2}{|c|}{ Total bacteria } & \multicolumn{2}{|c|}{$\begin{array}{c}\text { IAA producing } \\
\text { bacteria }\end{array}$} & \multicolumn{2}{|c|}{$\begin{array}{c}\text { Protease producing } \\
\text { bacteria }\end{array}$} & \multicolumn{2}{|c|}{$\begin{array}{c}\text { Phosphate solubilizing } \\
\text { bacteria }\end{array}$} \\
\hline Cult. & Fertilizer & 0 WAP & 12 WAP & O WAP & 12 WAP & O WAP & 12 WAP & O WAP & 12 WAP \\
\hline & & \multicolumn{8}{|c|}{$\left(\mathrm{CFU} \mathrm{mL} \mathrm{m}^{-1}\right) \times 10^{6}$} \\
\hline Mas Kirana & NPK & 16.167 & 29.500 & 29.667 & 5.833 & 29.667 & 14.000 & nd & 0.567 \\
\hline \multirow[t]{2}{*}{ (AA) } & $\mathrm{LOB}+1 / 2 \mathrm{NPK}$ & 67.333 & 633.333 & 225.333 & 278.833 & 9.500 & 189.500 & nd & 0.817 \\
\hline & LOB & 48.000 & 220.667 & 46.500 & 154.833 & 15.000 & 100.833 & 0.333 & 1.617 \\
\hline Cavendish & NPK & 39.333 & 311.667 & 61.167 & 19.167 & 17.167 & 2.500 & 1.217 & nd \\
\hline \multirow[t]{2}{*}{ (AAA) } & $\mathrm{LOB}+1 / 2 \mathrm{NPK}$ & 21.500 & 130.000 & 30.833 & 17.500 & 6.500 & 10.500 & 0.167 & 0.300 \\
\hline & LOB & 25.333 & 98.167 & 37.000 & 16.333 & 18.000 & 13.667 & 1.367 & 0.233 \\
\hline Barangan & NPK & 38.000 & 177.333 & 43.667 & 471.667 & 5.833 & 111.833 & 0.000 & 1.750 \\
\hline \multirow[t]{2}{*}{ (AAA) } & $\mathrm{LOB}+1 / 2 \mathrm{NPK}$ & 18.667 & 319.667 & 22.000 & 931.833 & 4.000 & 431.667 & 0.183 & 4.267 \\
\hline & LOB & 54.500 & 137.000 & 40.833 & 861.000 & 14.500 & 401.833 & 0.500 & 5.250 \\
\hline Raja Lido & NPK & 49.500 & 66.667 & 50.667 & 77.333 & 13.667 & 41.000 & 3.050 & 2.267 \\
\hline \multirow[t]{2}{*}{$(\mathrm{AAB})$} & $\mathrm{LOB}+1 / 2 \mathrm{NPK}$ & 52.500 & 52.500 & 27.333 & 247.333 & 14.167 & 42.667 & 0.100 & 8.800 \\
\hline & LOB & 24.333 & 175.000 & 34.500 & 276.000 & 32.167 & 137.333 & nd & 11.400 \\
\hline Raja Bulu & NPK & 88.667 & 285.500 & 44.500 & 52.667 & 15.667 & 46.333 & 0.283 & 0.100 \\
\hline \multirow[t]{2}{*}{$(\mathrm{AAB})$} & $\mathrm{LOB}+1 / 2 \mathrm{NPK}$ & 10.500 & 313.500 & 57.000 & 104.500 & 5.500 & 283.833 & nd & 2.783 \\
\hline & LOB & 15.667 & 193.833 & 24.333 & 235.000 & 11.333 & 206.000 & 0.050 & 0.333 \\
\hline Raja Sereh & NPK & 13.667 & 46.667 & 23.000 & 45.500 & 6.167 & 34.500 & nd & 1.900 \\
\hline \multirow[t]{2}{*}{$(\mathrm{AAB})$} & $\mathrm{LOB}+1 / 2 \mathrm{NPK}$ & 22.667 & 192.833 & 32.000 & 69.667 & 10.500 & 53.667 & 1.817 & 4.817 \\
\hline & LOB & 51.000 & 55.000 & 88.667 & 64.333 & 35.333 & 23.500 & 0.300 & 0.167 \\
\hline & NPK & 27.500 & 16.167 & 61.000 & 14.000 & 13.333 & 8.833 & 0.500 & 0.167 \\
\hline \multirow[t]{2}{*}{$(\mathrm{AAB})$} & $\mathrm{LOB}+1 / 2 \mathrm{NPK}$ & 17.500 & 17.667 & 18.333 & 14.000 & 9.000 & 7.333 & nd & 0.167 \\
\hline & LOB & 57.167 & 43.667 & 27.000 & 35.500 & 11.667 & 34.000 & 1.900 & 0.850 \\
\hline \multirow{3}{*}{ Kepok (ABB) } & NPK & 41.667 & 42.667 & 35.000 & 47.833 & 7.750 & 21.667 & nd & 0.167 \\
\hline & $\mathrm{LOB}+1 / 2 \mathrm{NPK}$ & 55.000 & 49.000 & 51.333 & 465.000 & 21.667 & 24.167 & 0.467 & 3.050 \\
\hline & LOB & 63.333 & 187.500 & 36.333 & 50.333 & 18.000 & 43.667 & nd & 2.233 \\
\hline
\end{tabular}

fertilizer and cultivar banana treatment

\section{Discussion}

The vegetative growth of bananas in the plantation is generally supported heavily with inorganic fertilizer and organic fertilizer to guarantee a desirable yield. The recommended inorganic fertilizer doses per plant per cycle are about $90 \mathrm{~g} \mathrm{~N}, 28 \mathrm{~g} \mathrm{P}$, and $182 \mathrm{~g} \mathrm{~K}_{2} \mathrm{O}$ doses per plant (Smithson et al. 2001) to $600 \mathrm{~g}$ Urea, $400 \mathrm{~g}$ TSP, $1550 \mathrm{~g}$ $\mathrm{KCl}$ (Suhartanto et al. 2012). Nomura et al. (2017) reported that to achieve maximum yield of banana cultivars like 'Nanicão IAC 2001' and 'Grand Naine', the farmers need application about $525 \mathrm{~kg} \mathrm{~N}^{-1}$ year $^{-1}$ and $855 \mathrm{~kg}$ $\mathrm{K}_{2} \mathrm{O}$ ha $^{-1}$ year $^{-1}$. Our inorganic fertilizer application dose we applied in this research are around $64 \mathrm{~kg} \mathrm{~N} \mathrm{ha}^{-1}, 64 \mathrm{~kg} \mathrm{P}$ ha $^{-1}$ and $218 \mathrm{~kg} \mathrm{~K}_{2} \mathrm{O} \mathrm{ha}{ }^{-1}$ is considered a moderate-rate fertilizer for bananas.

Our results showed that it was possible to reduce the use of inorganic fertilizer to $50 \%$ if compensated with the application of LOB without significantly reduced the growth rate as measured by pseudostem high and diameter, leaf number, and leaf size except for the most commercially important cultivar of Cavendish. The application of biofertilizer in combination with 50\% inorganic fertilizer in bananas has been demonstrated to show the best growth especially in some cultivars like Raja and Kepok; that could be due to the development of the root. Perdani et al. (2020) reported that the application of bio-organic fertilizer with $50 \%$ inorganic fertilizer increased fibrous root formation and the rate of mycorrhizal colonization in the roots of upland rice around
34\%. Ye et al. (2020) suggest using liquid organic bioorganic fertilizers combined with the correct dosage of chemical fertilizers for maximum yield benefits regarding yield, quality and fertilizer savings since it increases microflora abundance and improves soil fertility and in turn increases soil microbial activity. The benefit of biofertilizer application to reduce inorganic fertilizer doses without decreasing vegetative growth and yield have been demonstrated for many crops such as watermelon (Antonius and Agustiyani 2011), sorghum (Agustiyani et al. 2015), and tomato (Ye et al. 2020).

Application of LOB and 50\% inorganic fertilizer in sorghum resulted in comparable yield to the 100\% inorganic fertilizer application, however with Brix value higher than that of $100 \%$ inorganic fertilizer application (Agustiyani et al. 2015). The synergistic effect of PGPR and inorganic fertilizer on plant growth may be dialectic as it is explained as follows. The addition of $\mathrm{N}$ and $\mathrm{P}$ through mineral fertilizer (inorganic fertilizer) has influenced the biological process both directly and indirectly, including soil microbe (Damodaran et al. 2016). Bioorganic fertilizer when applied with NPK fertilizer increased cfu of bacteria. The increase in the number of bacteria in the root zone will increase the availability of nutrients that plants can absorb (Damodaran et al. 2014). Different fertilizer applications change the soil physical and chemical properties, which affects the soil bacterial and structure in rhizospheres soil (Rubiao et al. 2020). Mahdi et al. (2010) indicate that biofertilization is to accelerate the microbial processes 
necessary for nutrient availability that can be easily assimilated by plants and increase the number of useful microorganisms in the soil.

For Cavendish, interestingly, both treatments of inorganic fertilizer and combination of $50 \%$ inorganic fertilizer and LOB did not result in significantly different in regard to the number of leaves which is a significant determinant for fruit yield, even though the leaf size decreased significantly. A reduction in the leaf size of Cavendish due to limited availability of inorganic fertilizer could be one of the indicates of potassium deficiency that would further reduce the bunch yield (Taulya 2013). Mustafa and Kumar (2012) reported that the inorganic fertilizer application in Dwarf Cavendish showed increased growth and yield when plants supplied with $\left(\mathrm{g} \mathrm{plant}^{-1}\right) 72$ $200 \mathrm{~N}$; 90-96 P; and 150-480 K. The nutrient of N, P, and $\mathrm{K}$ rates given in this experiment may have been limited compared to the recommended doses for bananas, especially for Cavendish (Mustafa and Kumar 2012). Banana is a potassium loving crop, and has a very high demand for this nutrient. In India, the applied dose of $\mathrm{K}$ varies from 800 to $1600 \mathrm{~kg} \mathrm{ha}^{-1}$ (Kumar et al. 2008).

In this work, different cultivar showed different growth rates that may require different fertilizers doses. Differences between cultivars generally are difficult to assess from the literature since many cultivars have not been grown in the same climate with a differential nutrient supply. However, by comparing the nutrient concentrations in lamina-3 of 30 banana cultivars, Lahav (1995) reported that cultivars with a balbisiana constitution had lower concentrations of most elements than other species of acuminata based cultivars. Furthermore, this effect was carried over to cultivars with the balbisiana genome. Thus, each set of B genome contributed to lowering the concentrations of nutrients, i.e., cultivars with the AAA genome had higher levels than those with the AAB, and the latter higher than the $\mathrm{ABB}$. The report of nutrient in banana by Lahav (1995) is in line with our result that 'Kepok' (ABB) that have two balbisiana genome were more responsive to a lower fertilizer dose (treatment $100 \%$ LOB $+50 \%$ NPK or $100 \%$ LOB alone) than that of cultivars with more A genome.

Application of PGPR to enrich compost compared to regular compost has been demonstrated to increase yield of broccoli, carrot, and corn in an organic farming setup (Antonius et al. 2015). On the contrary, our result indicated that the application of LOB alone did not support satisfactory growth of banana plants; in fact, the vegetative growth of eight cultivars tested underwent severe reduction up to $50 \%$. The nutrient availability due to microbe nutrient solubilizing activity may be sufficient to support plant growth with little biomass but may not be sufficient for large biomass plant growth such as bananas. However, it is also interesting to note that the growth reduction on Kepok due to LOB application alone was merely 20-30\%. Thus, this result indicates the direct benefits of application LOB alone, which is easy and inexpensive to produce for smallholder farmers planting Kepok for cash crop or subsistence use.
LOB 'Beyonic' we used in this work contains plant growth-promoting rhizobacteria that have functions for nitrogen-fixing, potassium and phosphate solubilization, proteolytic activity, and growth hormone (IAA) secretion. Consequently, LOB inoculant is not a single strain but a mixed strain to bring the synergistic effect of nutrient mobilization, to enhance efficacy, stability, and uniformity when applied to different fields. LOB 'Beyonic' contains phosphate solubilizing bacteria that solubilize the fixed phosphate and make it bioavailable to plants. Phosphate solubilizing bacteria can transform insoluble phosphates into soluble forms by the excretion of organic acids in the rhizosphere. These organic acids decrease the soil $\mathrm{pH}$ and cause the dissolution of phosphate complexes and make them available to plants (Gupta, 2004). Protease producing bacteria might be related to biocontrol activity based on the ability to degrade the protein. PGPRs as biological agents have evidently to be alternatives to chemical agents for providing resistance against various pathogens' attacks (Backman and Sikora 2008). Itelima et al. (2018) reported Bacillus subtillis N11 and mature compost were found to control Fusarium infestation on the banana root. Microbes that can produce IAA can increase root growth and enhance root surface; eventually, plants can absorb more soil nutrients (Bolero et al. 2007).

During plant growth, application of LOB with or without inorganic fertilizer in the banana cultivars tested showed that the bacteria's total population generally increased significantly, and there was a synergistic effect of LOB and inorganic fertilizer in increasing the population of total bacteria population. LOB application as compost enrichment increases in the total population of bacteria and increases urease and phosphatase activity in the soil samples (Antonius et al. 2015). LOB application to ultisol soil alone or combined with compost and biochar increased the total microbe population significantly after ten weeks and coincided with the increasing soil enzyme activity of phosphomonoesterase and soil $\mathrm{P}$ availability (Antonius et al. 2018).

The increase in bacteria population with a specific function, such as protease activity, phosphate solubilizing activity and IAA producing activity, were attributed to the application of LOB. The increase of those bacteria populations with specific function due to LOB application was dependent upon the cultivars. For example, the total population of phosphate solubilizing bacteria in Raja Lido cultivar was the highest in LOB application only. Barangan cultivar has the highest total population of IAA producing bacteria compared to other cultivars. Barangan cultivar also has the highest population protease producing bacteria in the application of LOB and LOB $+50 \%$ NPK. The total population of protease-producing bacteria of Mas Kirana, Raja Bulu, Raja Sereh, Tanduk and Kepok increased in LOB application. The PGPR population difference may eventually affect biomass and yield. The different response in biomass and yield of genotypes to PGPR application has been demonstrated in many crops such as chickpea (Imran et al. 2015), barley (Shirinzadeh et al. 2013), and wheat (Rothballer et al. 2003). 
To conclude, we have demonstrated that LOB composed of a consortium of bacteria with many different plant growths promoting activities, such as IAA producing, phosphate and potassium solubilizing activities, protease activity; that have been proven to be effective to many plants could be applied with reduced inorganic fertilizer up to $50 \%$ without significant reduction on the plant growth variables in many different banana varieties, except for cultivar Cavendish. That treatment combination of inorganic and biofertilizer also increased the population of PGPR such as IAA producing, phosphate and potassium solubilizing, protease producing bacteria in the banana plant rhizospheres. Fine-tuning the microbial composition or the percentage of inorganic fertilizer reduction should be worthwhile for Cavendish since it is the most widely grown and traded banana cultivar in the world. Application of LOB alone in the event where the inorganic fertilizer is lacking, may be beneficial for Kepok as it was demonstrated that its vegetative growth reduction even though significant, was in a small percentage.

\section{ACKNOWLEDGEMENTS}

This research was funded by the DIPA program 20162018, Research Center for Biology, Indonesian Institute of Sciences, Bogor, Indonesia. The authors would also like to thank especially K. Utami Nugraheni, Herlina and Dian Mulyana and other staff members of the Laboratory of Plant Genetics and Breeding, Plant Cell and Tissue Cultures Laboratory, and Laboratory of Agricultural Microbiology for their technical assistance.

\section{REFERENCES}

Agustiyani D, Imamuddin H, Laili N, Dewi TK, Antonius S. 2015. Effect of application of chemical and liquid organic fertilizer LOB StarTmik on growth and yield of sorghum. Prosiding Seminar Nasional Hasil Penelitian Bidang Pangan Nabati. "Bioresources untuk Pembangunan Ekonomi Hijau”. Puslit Bioteknologi-LIPI, December 2015. [Indonesian]

Antonius S, Agustiyani D, Laili N, Hartati, Sutisna E. 2019. Pupuk organik cair dan proses pembuatannya. Paten Indonesia. No Patent IDP 000064813. [Indonesian]

Antonius S, Agustiyani D. 2011. Pengaruh pupuk organik hayati yang mengandung mikroba bermanfaat terhadap pertumbuhan dan hasil panen tanaman semangka serta sifat biokimia tanahnya pada percobaan lapangan di Malinau-Kalimantan Timur. Berk Penel Hayati 16: 203-206. [Indonesian]

Antonius S, Laili N, Imamuddin N, Agustiyani D. 2012. Development of sustainable agriculture: The role of Beyonic-StarTmik LIPI biofertilizer on yield improvement of various crops and conservation of soil biochemical properties of various ecosystems in Indonesia. In: Abdulhadi R, Tjahjono BSE, Waluyo EB, Delinom RM, Prijono SN, Fizzanty T, Lesmana T. (eds). Proceeding of "Mobilizing Science Toward Green Economy", The 12 th Sciences Council on Asia (SCA) Conference and International Symposium. Bogor. 10-12 July 2012.

Antonius S, Rahmansyah M, Muslichah DA. 2015. Pemanfaatan inokulan mikroba sebagai pengkaya kompos pada budidaya sayuran. Berita Biologi 14 (3): 223-234. [Indonesian]

Antonius S, Sahputra RD, Nuraini Y, Dewi TK. 2018. Manfaat pupuk organik hayati, kompos dan biochar pada pertumbuhan bawang merah dan pengaruhnya terhadap biokimia tanah pada percobaan pot menggunakan tanah ultisol. Jurnal Biologi Indonesia 14 (2): 243-250. [Indonesian]
Backman PA, Sikora RA. 2008. An emerging tool for biological control. Biol Control 6 (1): 1-3.

Bolero L, Perrig D, Masciarelli O, Penna C, Cassan F, Luna V. 2007. Phytohormone production by three strains of Bradyrhizobium japonicum and possible physiological and technological implications. Appl Microbiol Biotechnol 74 (4): 874-880. DOI: 10.1007/s00253006-0731-9.

Cappucino JG, Sherman N. 1987. Microbiology: A Laboratory Manual. The Benjamin/ Cummings Publishing Company, Inc, Belmont, CA.

Damodaran T, Bagyarai DJ, Ashwin R. 2016. Effect on chemical fertilizer on the beneficial soil microorganism. Fertilizer Environ News 2 (2): 10-11. DOI: 10.13140/RG.2.2.20802.79044.

Damodaran T, Rai RB, Jha SK, Kannan R, Pandey BK, Sah V, Mishra VK, Sharma DK. 2014. Rhizosphere and endophytic bacteria for induction of salt tolerance in gladiolus grown in sodic soils. J Plant Interact 9 (1): 577-584. DOI: 10.1080/17429145.2013.873958.

Danarto SA, Hapsari L. 2015. Biomass and carbon stock estimation inventory of Indonesian bananas (Musa spp.) and its potential role for land rehabilitation. Biotropia 22 (2): 102-108.

Dewi TK, Arum ES, Imamuddin H, Antonius S. 2015. Karakterisasi mikroba perakaran (PGPR) agen penting pendukung pupuk organik hayati. Proceeding of Seminar Nasional Masyarakat Biodiversitas 1 (2): 289-295. [Indonesian]

El Moniem EAA, Abd-Allah ASE, Ahmed MA. 2008. The combined effect of some organic manures, mineral $\mathrm{N}$ fertilizers and algal cell extract on yield and fruit quality of William banana plants. AmEurasian J Agric Envir Sci 4 (4): 417-426.

Ernawiati E, Agustrina R, Irawan B, Nurhasanah E, Kanedi M. 2018. Germplasm diversity of banana (Musa spp) in the city of Bandar Lampung, Indonesia by type of genome and number of chromosome. Sch J Agric Vet Sci 5 (4): 251-254. DOI: 10.21276/sjavs.2018.5.4.10.

Gamez R, Cardinale M, Montesa M, Ramirez S, Schnell S, Rodriguez F. 2019. Screening, plant growth promotion and root colonization pattern of two rhizobacteria (Pseudomonas fluorescens Ps006 and Bacillus amyloliquefaciens Bs006) on banana cv. Williams (Musa acuminata Colla). Microbiol Res 220: 12-20. DOI: 10.1016/j.micres.2018.11.006.

Gupta AK. 2004. The Complete Technology Book on Biofertilizer and Organic Farming. National Institute of Industrial Research Press, Delhi.

Gupta G, Parihar SS, Ahirwar NK, Snehi SK, Singh V. 2015. Plant growth-promoting rhizobacteria (PGPR): Current and future prospects for development of sustainable agriculture. J Microb BiochemTechnol 7 (2): 96-102

Gurav RG, Jadhav JP. 2013. A novel source of biofertilizer from feather biomass for banana cultivation. Environ Sci Pollut Res Int 20 (7): 4532-4539. DOI: 10.1007/s11356-012-1405-z.

Hapsari L. 2014. Wild Musa species collection of Purwodadi Botanic Garden: Inventory and its morpho-taxonomic review. J Trop Life Sci 4 (1): 70-80.

Imran A, Mirza M, Shah TM, Malik K. Hafeez F. 2015. Differential response of Kabuli and Desi chickpea genotypes toward inoculation with PGPR in different soils. Front Microbiol 6: 859. DOI: 10.3389/fmicb.2015.00859.

Itelima JU, Bang WJ, Onyimba IA, Sila MD, Egbere OJ. 2018. A review: Biofertilizer; a key player in enhancing soil fertility and crop productivity. J Microbiol Biotechnol Rep 2 (1): 22-28.

Kumar D, Pandey V, Anjaneyulu, K. 2008. Effect of planting density and nutrient management on growth, yield and quality of micro propagated banana Rasthali (AAB-Pathkapoora). Indian J Hort 65: 272-276.

Lahav E. 1995. Banana nutrition. In: Gowen S. (eds) Bananas and Plantains. World Crop Series. Springer, Dordrecht. DOI: 10.1007/978-94-011-0737-2_11.

Li LF, Wang HY, Zhang C, Wang XF, Shi FX, Chen WN, Ge XJ. 2013. Origins and domestication of cultivated banana inferred from chloroplast and nuclear genes. PLoS ONE 8 (11): e80502. DOI: 10.1371/journal.pone.0080502.

Mahdi SS, Hassan GI, Samoon SA, Rather HA, Dar SA, Zehra B. 2010. Bio-fertilizers in organic agriculture. J Phytol 2 (10): 42-54.

Mia MAB, Shamsuddin ZH, Wahab Z, Marziah M. 2005. High-yielding and quality banana production through plant growth-promoting rhizobacterial inoculation. Fruits 60: 179-185. DOI: 10.1051/fruits:2005024

Mia MAB, Shamsuddin ZH, Wahab Z, Marziah M. 2010. Rhizobacteria as bioenhancer and biofertilizer for growth and yield of banana (Musa 
spp. cv. 'Berangan'). Sci Hortic-Amsterdam 126: 80-87. DOI: 10.1016/j.scienta.2010.06.005.

Moat AG, Foster JW, Spector MP. 2002. Microbial Physiology $4^{\text {th }}$ ed. Wiley-Liss Inc, New York.

Molina AB, Hermanto C, Pattison T, Subandiyah S, Winarno, Sukarman. 2019. Final Report: Integrated crop production of bananas in Indonesia and Australia. Project Report. ACIAR https://www.aciar.gov.au/project/HORT-2008-040.

Mustafa MM, Kumar V. 2012. Banana production and productivity enhancement through spatial, water and nutrient management. J Hortic Sci 7 (1): 1-28.

Nasution RE, Yamada I. 2001. Pisang-Pisang Liar di Indonesia. Puslitbang Biologi-LIPI, Bogor. [Indonesian]

Nomura ES, Cuquel FL, Junior ERD, Fuzitani EJ, Borges AL. 2017 Fertilization with nitrogen and potassium in banana cultivars 'Grand Naine', 'FHIA 17' and 'Nanicão IAC 2001' cultivated in Ribeira Valley, São Paulo State, Brazil. Acta Sci-Agron 39 (4): 505-513. DOI: 10.4025/actasciagron. v39i4.32919.

Peraturan Menteri Pertanian Republik Indonesia No. 01 Tahun 2019 tentang Pendaftaran Pupuk Organik, Pupuk Hayati dan Pembenah Tanah. 2 Januari 2019, Jakarta. [Indonesian]

Perdani AY, Dewi TK, Widowati T, Zulfitri A, Praharyawan S. 2020 Utilization of bio-organic fertilizers for increasing upland rice production. IOP Conf Ser Earth Environ Sci 439: 012011. DOI: 10.1088/1755-1315/439/1/012011.

Perrier X, de Langhe E, Donohue M, Lentfer C, Vrydaghs L, Bakry F, Carreel F, Hippolyte I, Horry JP, Jenny C, Lebot V, Risterucci AM, Tomekpe K, Deutrolepont H, Ball T, Manwaring J, de Maret P, Denham T. 2011. Multidisciplinary perspectives on banana (Musa spp.) domestication. Proc Nat Acad Sci USA. DOI: 10.1073/ pnas. 1102001108

Poerba YS, Handayani T, Ahmad F, Martanti D, Witjaksono. 2018 Deskripsi Pisang: Koleksi Pusat Penelitian Biologi LIPI. LIPI Press, Bogor. [Indonesian]

Poerba YS, Martanti D, Ahmad F. 2019. Genetic variation of wild Musa acuminata Colla in Indonesia. Biotropia 26 (2). DOI 10.11598/btb.2019.26.2.896.

Posada LF, Ramirez M, Ochoa-Gomez N, Cuellar-Gaviria TZ, ArgelRoldan LE, Ramirez CA, Villegas-Escobar V. 2016. Bioprospecting of aerobic endospore-forming bacteria with biotechnological potentia for growth promotion of banana plants. Sci Hortic-Amsterdam 212: 81-90. DOI: 10.1016/j.scienta.2016.09.040.

Rothballer M, Schmid M, Hartmann A. 2003. In situ localization and PGPR effect of Azospirillum brasilense strains colonizing roots of different wheat varieties. Symbiosis 34: 261-279.

Rubiao L, Ruixing H, Jing L, Al E. 2020. Effects of different fertilizers on rhizosphere bacterial communities of winter wheat in the North China Plain. Agronomy 10 (1): 93. DOI: 10.3390/agronomy10010093.

Santosa S, Sutarno, Purwanto E, Suranto, Sajidan. 2018. Molecular characterization of plant growth-promoting rhizobacteria using $16 \mathrm{~s}$ rRNA sequences in the organic rice field of Sukorejo Village, Central Java, Indonesia. Biodiversitas 19 (6): 2157-2162. DOI: 10.13057/biodiv/d190623.

Shirinzadeh A, Soleimanzadeh H, Shirinzadeh Z. 2013. Effect of seed priming with plant growth-promoting rhizobacteria (PGPR) on agronomic traits and yield of barley cultivars. World Appl Sci J 21 (5): 727-731. DOI: 10.5829/idosi.wasj.2013.21.5.1749.

Smithson PC, McIntyre BD, Gold CS, Ssali H, Kashaija IN. 2001. Nitrogen and potassium fertilizer vs nematode and weevil effects on yield and foliar nutrient status of banana in Uganda. Nutr Cycl Agroecosyst 59: 239-250.

SNI 2897. 2008. Metode Pengujian Cemaran Mikroba dalam Daging, Telur dan Susu Serta Hasil Olahannya. [Indonesian]

Suhartanto R, Sobir, Harti H. 2012. Teknologi Sehat Budidaya Pisang: Dari Benih Sampai Pasca Panen. Pusat Kajian Hortikultura Tropika, Lembaga Penelitian dan Pengabdian Kepada Masyarakat Institut Pertanian Bogor, Bogor. [Indonesian]

Suyamto ID, Sutanto A. 2012. Banana Reseach and Development in Indonesia: Updates and Highlights. Advancing banana and plantain R\&D in Asia and the Pacific 13: 81-88.

Taulya G. 2013. East African highland bananas (Musa spp. AAA-EA) 'worry' more about potassium deficiency than drought stress. Field Crops Res 151: 45-55. DOI: 10.1016/j.fcr.2010.01.011.

Ye L, Zhao X, Bao E, Li J, Zou Z, Cao K. 2020. Bio-organic fertilizer with reduced rates of chemical fertilization improves soil fertility and enhances tomato yield and quality. Nat Sci Rep 10: 177. DOI: 10.1038/s41598-019-56954-2.

Zhang N, He X, Zhang J, Raza W, Yang XM, Ruan, YZ, Shen QR, Huang QW. 2014. Suppression of Fusarium Wilt of banana with application of bio-organic fertilizer. Pedosphere 24 (5): 613-624. 